\title{
FIRST RECORD OF CALOCHORTUS APICULATUS (LILIACEAE) IN WYOMING
}

\author{
Joseph R. Thomasson ${ }^{1}$, Scott A. Thomasson ${ }^{1}$, and Daryl E. Mergen ${ }^{2}$
}

Key words: Calochortus apiculatus, distribution, Black Hills, Wyoming, disjunct.

Baker’s mariposa lily, Calochortus apiculatus Baker, has a limited distribution that includes northwestern Montana, the upper panhandle of Idaho, far northeastern Washington, and small areas in southern British Columbia and Alberta (Fiedler and Zebell 2003). Three other species of Calochortus with mostly glabrous petals, erect capsules, and larger flowers (Calochortus nuttallii T. \& G., C. gunnisonii Wats., and C. eurycarpus Wats.) occur in Wyoming, sometimes in similar habitats; however, $C$. apiculatus, with smaller flowers, strongly nodding capsules, and pubescent petals, has not previously been reported from the Black Hills of South Dakota or Wyoming (D. Ode, botanist, South Dakota Natural Heritage Database, personal communication; B. Heidel, Wyoming Natural Diversity Database, personal communication).

On 20 July 2004, the senior and 2nd authors observed more than 50 flowering and fruiting individuals of $C$. apiculatus while conducting surveys of sensitive plants in the Black Hills of northeastern Wyoming. Plants were observed and collected on level to slightly inclined $\left(<10^{\circ}\right)$ south- to west-facing slopes in a dry, open Pinus ponderosa forest in association with Juniperus communis, Mahonia repens, Piptatherum pungens, Lupinus argenteus, and Arctostaphylos uva-ursi at an elevation of $1865 \mathrm{~m}$. The locality was in Crook County, Wyoming, about 0.25 $\mathrm{km}$ northwest of the Wyoming-South Dakota border along Wagon Canyon Road (UTM NAD27, zone 13, 0575088E, 4906625N) in the NE1/4 NE1/4 sec 21, T50N, R60W, Old Baldy Mountain USGS Quadrangle. On 23 August 2004 the 3rd author returned and observed 2 plants with dehiscent fruits. Specimens collected for study (J.R. and S.A. Thomasson 3135) are deposited in the Elam Bartholomew Herbarium (FHKSC) at the Sternberg Museum of Natural History (FHKSC 33976 and 33977), the Black Hills State University Herbarium (BHSC), and the Rocky Mountain Herbarium (RM) at the University of Wyoming.

The genus Calochortus (circa 67 species) is distributed from Guatemala and Mexico north to British Columbia and east as far as Nebraska, South Dakota, and Colorado. With California as a center of diversity, species have undergone extensive evolutionary adaptations and inhabit a wide variety of habitats from deserts to moist mountain forests. Recent studies of molecular phylogeny (cpDNA) have identified 7 geographically cohesive clades centered mostly in the California Floristic Province, but also including a Pacific Northwest clade of 17 species to which C. apiculatus belongs (Patterson and Givnish 2003). Of the 3 other species of Calochortus occurring in Wyoming, C. gunnisonii and C. nuttallii are found statewide in dry habitats from open grasslands to open slopes in montane forests and belong to the Great Basin-Rocky Mountains clade, while $C$. eurycarpus is restricted to grasslands and open coniferous forests in the northwest and belongs to the Pacific Northwest clade. Both C. apiculatus and C. eurycarpus have a base chromosome number of 10 , and C. gunnisonii and $C$. nuttallii have a base number of 8 (Patterson and Givnish 2003). The 3 latter species exhibit the Mariposa floral syndrome with visually conspicuous, brightly colored flowers adapted to open conditions (Givnish and Patterson 2000), while $C$. apiculatus displays the cat's ears floral syndrome in which flowers have pubescent inner petal surfaces (Ownbey 1940). Although the functional significance of the cat's ears

1Department of Biological Sciences, Sternberg Museum of Natural History, Fort Hays State University, Hays, KS 67601.
${ }^{2}$ Mergen Ecological Delineations Inc., 1835 Parkview Blvd., Colorado Springs, CO 80906. 
syndrome is unclear, hairs on the inner surface of the petals may trap heat at higher altitude habitats in which members of this group generally occur (Patterson and Givnish 2003). Results of cpDNA phylogentic studies indicate C. gunnisonii and C. nuttallii are closely related and distinct from C. apiculatus and C. eurycarpus, which are also closely related (Patterson and Givnish 2003).

The discovery of a population of C. apiculatus, apparently isolated more than $600 \mathrm{~km}$ southeast of its known distribution range, seems significant, especially considering seed dispersal in Calochortus. Fruits are capsules borne close to the ground with heavy seeds lacking fleshiness or hairs for attachment (1 species has winged seeds; Bullock 1976, Patterson and Givnish 2003). Although the exact reason for the apparent isolation of C. apiculatus in Wyoming is unknown, the biogeographical uniqueness of a Black Hills flora that includes significant affinities with taxa from the Rocky Mountain region (at least 30\%) and many Northern Boreal Conifer Forest disjuncts has been recognized by others (McIntosh 1931, Marriott 1985, Strong and Hills 2003). Selected disjuncts in the Black Hills from these regions come from a broad array of taxonomic groups and include, among others, white spruce (Picea glauca), striped coral-root orchid (Corallorhiza striata), bunchberry (Cornus canadensis), blue columbine (Aquilegia brevistyla), and ground pine (Lycopodium dendroideum). Wright (1970) suggested that increasingly drier and warmer climates during the Pleistocene-Holocene reduced the distribution of coniferous forests that previously had been continuous across the northern Great Plains region, including the Dakotas, Wyoming, and Montana, and replaced them with a mosaic of open, drier prairies and more mesic, elevated forests in mountainous areas such as the Black Hills in which these disjuncts survived. More recent work by Strong and Hills (2003) in western Alberta supports the role of warmer and drier climate conditions during the Holocene Hypsithermal (9000-6000 cal yr BP) and subsequent cooling of the climate during post-Hypsithermal with the isolation of disjuncts in the Rocky Mountains and Peace River District of Alberta. This provides a model, as yet untested, for the origin of Black Hills disjuncts such as C. apiculatus. Alternately, the discovery of C. apiculatus in Wyoming as an apparently disjunct population may be a col- lecting artifact due either to a decline in plant collecting (Prather et al. 2004) or other reasons. For example, the 3rd author, with a knowledge of the exact locality of the newly observed population, was able, despite an extensive search, to locate only 2 plants $<1$ month after flowering and fruiting plants had been seen easily from a distance of several meters. The leaves, stems, and fruits had dried, shriveled, and turned brown during the month prior to his search making later recognition of the plants of C. apiculatus very difficult. Since the taxon occurs among grasses and other monocots with superficially similar stems and leaves, it may be that the combination of a morphological similarity to other taxa, a short flowering period (when easily recognized), and rapidly maturing and disintegrating fruits has made $C$. apiculatus difficult to recognize in past field studies. Finally, Fiedler and Zebell (2003) report that bulbs of some Calochortus were eaten by Native Americans, and perhaps bulbs of $C$. apiculatus were transported originally from a more distant location (e.g., southwestern Montana) and planted in the Black Hills. Additional investigations are in progress to determine the exact status and distribution of this taxon in the Black Hills.

Botanical surveys in the Black Hills were conducted under contracts from the USDA Forest Service to Mergen Ecological Delineations, Inc. We thank the USDA Forest Service for granting permission to use the data in this report and S. Corey and K. Zacharkevics of the USDA Forest Service for supporting and facilitating surveys associated with the discovery of C. apiculatus in the Black Hills. We also thank R.L. Hartman and P. Lesica for reviewing the manuscript and providing helpful comments and suggestions that substantially improved it. P.L. Fiedler graciously confirmed our identification of C. apiculatus. Funds from the Elam Bartholomew Herbarium Endowment Fund helped support this study.

\section{Literature Cited}

BulLOCK, S.H. 1976. Comparison of the distribution of seed and parent-plant populations. Southwestern Naturalist 21:383-389.

Fiedler, P.L., AND R.K. Zebell. 2003. Calochortus. Pages 119-141 in Flora of North America Editorial Committee, Flora of North America North of Mexico. Volume 26: Liliidae. Oxford University Press, New York. 
Givnish, T.J., AND T.B. Patterson. 2000. Adaptive radiation: concerted convergence and the crucial contribution of molecular systematics. Pages 97-110 in K. Iwatsuki, editor, IIAS International Symposium on Biodiversity. International Institute for Advanced Studies, Kyota, Japan.

MarriotT, H. 1985. Flora of the northwestern Black Hills, Crook and Weston Counties, Wyoming. Master's thesis, University of Wyoming. 93 pp.

McIntosh, A.J. 1931. A botanical survey of the Black Hills of South Dakota. Black Hills Engineer 19:159-276.

OwnBey, M. 1940. A monograph of the genus Calochortus. Annals of the Missouri Botanical Garden 27: 371-560.

Patterson, T.B., and T.J. Givnish. 2003. Geographic cohesion, chromosomal evolution, parallel adaptive radiations, and consequent floral adaptations in Calochor- tus (Calochortaceae): evidence from cpDNA phylogeny. New Phytologist 161:253-264.

Prather, A.L., O. Alvarez-Fuentes, M.H. Mayfield, and C.J. Ferguson. 2004. Implications of the decline in plant collecting for systematic and floristic research. Systematic Botany 29:216-220.

Strong, W.L., AND L.V. Hills. 2003. Post-Hypsithermal plant disjunctions in western Alberta, Canada. Journal of Biogeography 30:419-430.

Wright, H.E., JR. 1970. Vegetational history of the Great Plains. Pages 157-172 in W.D. Dort and J.K. Jones, Jr., editors, Pleistocene and Recent environments of the central Great Plains. University Press of Kansas, Lawrence.

Received 11 November 2004 Accepted 4 August 2005 